\title{
Chapter 2 \\ Public-Private-People Partnership Networks and Stakeholder Roles Within MaaS Ecosystems
}

\author{
Jenni Eckhardt \\ (iD) https://orcid.org/0000-0002-6089-7986 \\ VTT Technical Research Centre of Finland Ltd., Finland \\ Aki Aapaoja \\ (iD) https://orcid.org/0000-0002-6968-3191 \\ VTT Technical Research Centre of Finland Ltd., Finland \\ Harri Haapasalo \\ (iD) https://orcid.org/0000-0001-5413-5638 \\ University of Oulu, Finland
}

\begin{abstract}
Mobility as a service (MaaS) is an emerging concept offering integrated mobility services. Combining different transportmodes and services, as well as collaboration of stakeholders, are prerequisites for viable and attractive MaaS services. MaaS is expected to increase the sustainability and efficiency of transport. Public-privatepeople partnership (PPPP) networks are seen as a potential solution to meet these expectations, especially in rural areas. The purpose here is to present a PPPP network for MaaS, which integrates market-based mobility services and subsidized transportation. The chapter also describes the roles and responsibilities of primary and secondary MaaS stakeholders at different levels, including authority, service provider, MaaS operator, and user levels.
\end{abstract}




\section{INTRODUCTION}

Several trends and drivers are pushing demand for new mobility services. Targets to reduce greenhouse gas emissions require measures such as new sources of lowemission fuel, technological development of vehicles, and improving the energy efficiency of transport systems through services (Särkijärvi, Jääskeläinen, \& LohkoSoner, 2018). New mobility concepts are seen as a significant opportunity to bring about low-carbon mobility (European Commission, 2017a). As public funding decreases, pressure is growing to produce more efficient subsidized transport services. Urbanization results in increased congestion, as well as land use and parking problems, while causing more challenges in rural areas to provide efficient transport and viable mobility services. Advances in technology and digitalization enable integrated travel chains and shared services via smartphones and mobile applications (e.g. Hallock \& Inglis, 2015). User behavior is also changing; younger generations are not as keen to own a car and customers are more environmentally oriented and open to circular economy services (Heikkilä, 2014). It has been recognized that technology-enabled transportation services have the potential to reduce driving and car ownership (Hallock \& Inglis, 2015). In addition, reduction of car ownership may also relate to life events and income reductions (Clark, Chatterjee, \& Melia, 2016).

Mobility as a Service (MaaS) is an emerging concept of integrated transport services that is seen as a solution to tackling future mobility challenges and meeting new customer needs. In rural areas, MaaS can increase efficiency of transport and accessibility of remote areas (Eckhardt, Nykänen, Aapaoja, \& Niemi, 2018). Publicprivate partnerships (PPP) have been recommended for MaaS (National Academies of Sciences, Engineering, and Medicine, 2016; Eckhardt et al., 2017a; Polis, 2017; ERTICO, 2018). PPP refers to cooperation between public-private actors in which they jointly develop services and share risks, costs and resources which are connected with these services (Van Ham \& Koppenjan, 2001).

The objective of this chapter is to present a potential public-private-people partnership (PPPP) network for MaaS, bringing in the 'people' aspect in terms of prosuming, where users both use and produce services. The aim is also to identify stakeholders within the MaaS ecosystem and define their roles. The chapter deals with the following research questions:

- What kind of PPPP networks can be created for rural MaaS?

- Who are the stakeholders involved in MaaS ecosystems?

- What are the roles and responsibilities of the identified stakeholders? 
The chapter is structured as follows: A review of the literature describes the MaaS concept and relevant discussions on PPP and PPPP, as well as business and stakeholder networks. Next is a description of the adopted methodology (interviews and stakeholder workshops) and results for the PPPP network in the rural context and MaaS stakeholders, including roles and responsibilities. The results are discussed and followed by concluding remarks.

\section{CONTEXT AND LITERATURE REVIEW}

Mobility as a Service (MaaS) is an emerging concept of transport services. MaaS refers to "multimodal and sustainable mobility services addressing customers" transport needs by integrating planning and payment on a one-stop-shop principle" (MAASiFiE, 2016). Hietanen (2014) defines MaaS as "a mobility distribution model in which a customer's primary transportation needs are met over one interface and are offered by a service provider" (p. 2). MaaS could offer travelers easy, flexible, reliable, priceworthy and environmentally sustainable everyday travel, such as public transport, carsharing and car leasing, as well as more efficient goods shipping and delivery possibilities (European Commission, 2017b).

The main characteristics of different MaaS definitions and descriptions include customer-orientation and integrated services (e.g. Hietanen 2014; Burrows, Bradburn, \& Cohen, 2015; Kamargianni, Li, \& Matyas, 2016; König, Eckhardt, Aapaoja, Sochor, \& Karlsson, 2016a; Transport Systems Catapult, 2016; MaaS Alliance, 2017; ERTICO, 2018). Integration also has several classifications. Shared mobility, Booking/Ticketing and Multimodal traveler information are the components of integration that König et al. (2016a) consider a MaaS service. Mobility services with fewer integration components could be considered MaaS-related services (König et al., 2016a). Kamargianni et al. (2016) have classified integration of MaaS in Ticket \& Payment integration, Mobility package and ICT integration. Lyons, Hammond, and Mackay (2019) propose Levels of MaaS Integration (LMI) taxonomy including operational and cognitive user efforts and suggest that operational and informational integration should be principal determinants of scaling up MaaS. Sochor, Arby, Karlsson, and Sarasini (2018) have classified the following integration levels:

0. No integration: Single, separate services

1. Integration of Information: Multimodal travel planner, price info

2. Integration of Booking and Payment: Single trip - find, book and pay

3. Integration of Service Offer: Bundling/subscription, contracts, etc.

4. Integration of Societal Goals: Policies, incentives, etc. 
The Netherlands Institute for Transport Policy Analysis proposes that integration level 2 of the classification by Sochor et al. (2018) would be the minimum level for MaaS (Harms, Durand, Hoogendoorn-Lanser, \& Zijlstra, 2018). Even though mobility packages and subscriptions exist, such as Whim (n.d.) monthly packages, pay-as-you-go is a commonly offered tariff option of MaaS services (Jittrapirom et al., 2017).

The aspect of sustainability appears more rarely in definitions (e.g. MAASiFiE, 2016; König et al., 2016a; European Commission, 2017b; ERTICO, 2018), but new mobility concepts are seen as a major opportunity to bring about low-carbon mobility (European Commission, 2017a). Other attempts to mitigate environmental impact include zero or low-emission vehicles and optimizing the transport system, including measures such as multimodality and digital mobility (European Commission, 2016). Digital technologies can make transport more efficient and inclusive and enable seamless door-to-door mobility and value-added services (European Commission, 2016).

MaaS is expected to provide several benefits related to low-carbon mobility, such as a modal shift from car to public transport and sharing services, an increase in multimodal trips and resource efficiency, and decreased emissions (Karlsson, Sochor, Aapaoja, Eckhardt, \& König, 2017). According to a global stakeholder survey, $80 \%$ of respondents expected private car use to be significantly reduced due to MaaS (König, Sochor, Eckhardt, \& Böhm, 2016b). In Sweden, the UbiGo MaaS pilot in an urban context showed attitude changes towards various travel modes: participants became less positive towards the private car and more positive towards alternative modes such as carsharing, bus/tram and bikesharing (Sochor, Karlsson, \& Strömberg, 2016). Particularly for younger generations, renting and sharing mobility services are increasingly popular and owning a private vehicle is becoming less important (European Commission, 2017a).

Goods deliveries are also connected to MaaS (e.g. Eckhardt et al., 2017a; European Commission, 2017b; MaaS Alliance, 2017; Jittrapirom et al., 2017). However, they are considered an additional feature and most of the MaaS services and pilots do not include freight services. A MaaS operator could, in addition to the mobility of people, include last-mile deliveries such as parcel, post, shopping, pharmacy products and meal deliveries. (Eckhardt et al., 2017a). Combining transport of goods is considered more relevant for rural areas due to long distances, sparse population and narrow flows of people and goods (Eckhardt et al., 2017a).

MaaS relies on existing public transport and is expanded with additional services, such as sharing services and taxis (Eckhardt et al., 2017a; Jittrapirom et al., 2017). However, rural areas have limited or even non-existing public transport, which challenges accessibility. Thus, rural solutions could include e.g. on-demand transport and sharing services (International Transport Forum, 2015; Eckhardt et 
al., 2018), as well as integrating social and health service and school transportation with commercial transportation (Eckhardt et al., 2018; The Finnish Innovation Fund Sitra, n.d.).

Shared mobility in its various forms supports the MaaS concept (e.g. Hallock \& Inglis, 2015; Shaheen, Cohen, \& Zohdy, 2016). Shared mobility refers to shared use of a motor vehicle, bicycle, or other low-speed transportation mode enabling users to obtain short-term access to transportation as needed, without requiring ownership (Shaheen et al., 2016). Several types of sharing services in the transportation sector already exist. There are commercial carsharing companies (e.g. DriveNow, ZipCar) and bike-sharing services, and some include both car and bike sharing (e.g. DB/ DIMIS) (Eckhardt et al., 2017a). The sharing services that private people offer include peer-to-peer carsharing services (e.g. Blox Car) and ridesharing services (e.g. BlaBlaCar) (Eckhardt et al., 2017a). There are also organized hitchhiking services, and e.g. Rezo Pouce was developed to assist with rural mobility (Rezo Pouce, n.d.). Ridesourcing services, such as Lyft or Uber, connect drivers and customers via smartphone application, and are also used for trips when public transit is not available (National Academies of Sciences, Engineering, and Medicine, 2016). In this changing era of new mobility, the meaning of public transport is changing towards 'passenger transport services by shared resources' (Laurell, 2017).

The transport sector is the largest in value utilizing PPP (European PPP Expertise Centre, 2018). PPP is widely used for transport infrastructure projects but is also related to e.g. transport technology and services. New mobility services should be developed in collaboration with the private sector and local and transport authorities, to support city and regional transport priorities and policies (Polis, 2017). MaaS has the potential to improve the efficiency of existing transport services and public resources (Polis, 2017; Eckhardt et al., 2018; ERTICO, 2018). However, new models and tools for public-private collaboration are needed to effectively govern the development and spreading of sustainable MaaS (Smith, Sarasini, Karlsson, Mukhtar-Landgren, \& Sochor, 2019a).

The generally recognized motivation for PPP is improved value for money (Organisation for Economic Cooperation and Development, 2012; Eadie, Millar, \& Toner, 2013; European PPP Expertise Centre, 2015). PPP also enables combining public and private expertise efficiently (European Union, 2018). In addition, PPP may improve existing public sector practices and promote more innovative ways of delivering public services (European PPP Expertise Centre, 2015). Large-scale deployments of MaaS necessitate extensive modifications to current business models and business relations, making public-private open innovation challenging (Smith, Sochor, \& Karlsson, 2019b). PPP contracts can be complex and resource intensive, and lack of public sector capacity and experience is one of the main challenges for PPPs (Organisation for Economic Cooperation and Development, 2012; European 
PPP Expertise Centre, 2015). Potential negative factors of PPP also include delays in negotiation, time-consuming management and high participation costs (Li, Akintoye, Edwards, \& Hardcastle, 2005).

Public-private-people partnership (PPPP, 4P) introducing the 'people' aspect has been studied related to e.g. urban development process, real estate industry and infrastructure building (e.g. Majamaa, 2008), as well as to the city resiliencebuilding process (Marana, Labaka, \& Sarriegi, 2018). PPPP is also related to Living Lab activities, including MaaS development (Jin \& Qiu, 2019). However, in these examples, 'people' implies participating in planning through discussion and ideas. Here, 'people' also refers to an active stakeholder who would consume and produce mobility services as a 'prosumer'. Prosumers could integrate e.g. private cars into the MaaS ecosystem in the form of ridesharing and peer-to-peer carsharing services (Eckhardt et al., 2017a).

To understand the current state of the MaaS ecosystem, this study applies the approach of network theory. Ultimately an ecosystem is a network - and a system also - comprising various interconnected actors having relationships between each other and the surrounding environment (Rubenstein-Montano et al., 2001). Network thinking depends heavily on how a system is defined, since it studies interconnections between the different parts of the network. Boundaries must be set to separate what parts of the world are contained inside the system and what parts are considered the external environment (e.g. internal and external stakeholders) (Leviäkangas et al., 2014). An example of these network theories is a well-known ARA network approach defining networks as constellations of Activities Resources and Actors (Håkansson \& Johanson, 1992). Studies on value-creating networks describe the operations and partially evolutionary nature of networks, giving insight also into the role of the public sector from the business point of view. Value networks open up possibilities to see benefits beyond organizational boundaries and improve efficiency through collaboration.

A business ecosystem is an economic community and a network supported by a set of interacting participants and organizations. Ecosystem participants can coevolve and co-create competences and skills around innovations by collaborating to create and support new offerings, satisfy customer needs and eventually discover innovations (Moore, 1993). A business ecosystem is defined by Iansiti and Levien (2004) as "loose networks - of suppliers, distributors, outsourcing firms, makers of related products or services, technology providers, and a host of other organizations - that affect and are affected by the creation and delivery of a company's offerings" (p. 68). Ecosystems are not static and may include not only private companies, but also authorities and other public organizations (Peltoniemi \& Vuori, 2004). Also, rival companies may be a part of the same ecosystem. One of the first publications in the ecosystems literature, "Predators and prey" by Moore (1993), descriptively 
presents the idea of evolution in ecosystems. The nature of this definition includes the assumption that ecosystems evolve and also hook in new participants, i.e. the ecosystem itself evolves according to its actors, which is also the basic element of a business network. In developing (or more likely guiding the evolution of) these networks, their former nature needs to be understood and the 'food chain' recognized in order to build economically viable ecosystems.

A key benefit of business ecosystems is that individual participants may gain or achieve more value within the ecosystem than they could by themselves (Adner, 2006), or incur fewer costs than operating alone. Typically, business ecosystems aim at extending the offering or co-developing it with others in various ways. Additionally, they can open up possibilities in new markets or enhance resource and asset utilization.

In this study, the participants or actors of ecosystems are called stakeholders. A stakeholder is any group or individual that affects or is affected by the organization's behavior (Freeman, 1984). Stakeholders are generally divided into primary and secondary (e.g. Freeman, 1984; Clarkson, 1995; Eesley \& Lenox, 2006) or even tertiary stakeholders (Aapaoja \& Haapasalo, 2014). The participation of primary stakeholders is required for the survival of an organization. These include e.g. customers, suppliers and public stakeholder groups (the governments and communities providing e.g. infrastructure, laws and regulations) (Clarkson, 1995). Stakeholders can also be seen as internal or external (Kinnunen, Aapaoja, \& Haapasalo, 2014). Internal stakeholders are inside the ecosystem. External stakeholders are not formal members of the ecosystem but may have an impact on or be impacted by the ecosystem (Cleland, 1986; Winch \& Bonke, 2004). Stakeholder identification and periodization of the most salient stakeholders is critical to achieve at least a reasonable amount of transparency and an economically viable ecosystem (Aapaoja \& Haapasalo, 2014). MaaS involves an 'ecosystem' including several stakeholders from both the public and private sectors. A MaaS ecosystem combines different variations of PPP and consists of four levels: 1) public and regulatory level;2) transport and logistics service provider level (i.e., supply-side); 3) mobility service level ('a MaaS operator'), and 4) end-user level (Aapaoja, Eckhardt, Nykänen, \& Sochor, 2017).

\section{METHODOLOGY}

The research methodology (Figure 1) includes five steps: a literature review, interviews, workshops, results and consolidation (Eckhardt et al., 2017a; Eckhardt, Nykänen, Aapaoja, \& Niemi, 2017b). The literature review was conducted first and consisted of the Mobility as a Service, public-private partnership, and business and stakeholder network theories. 
Figure 1. Methodology

Literature
MaaS, PPP,
business and
stakeholder
network
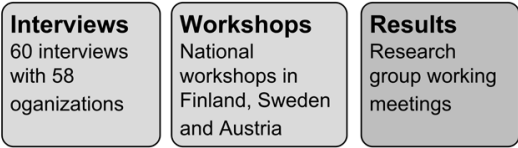

Qualitative data was then collected through interviews and workshops. The interviews consisted of 60 thematic interviews with 58 organizations (Table 1). The first set of interviews, half of the total, dealt with Maas covering different geographical areas and were performed internationally. The second set focused on MaaS in rural areas and were with Finnish stakeholders only. The interviewees were selected based on their expertise in the MaaS field and to ensure coverage of widely different stakeholder groups and geographical areas; thus they were from different counties or parts of Finland. All the interviews were conducted similarly on a semi-structured basis (Yin, 2003) and included questions related to MaaS networks and stakeholders, e.g.:

- What kind of service combination could be created for different geographical areas? (First set of interviews) / What kind of service combination could be created for rural areas? (Second set of interviews)

- How could freight transport be combined with the mobility of people?

- Who would be the main player or MaaS operator?

- Who are the main stakeholders and what would their roles be?

- What are the enablers/barriers of/to MaaS?

MaaS operators or service providers were also asked about their current roles and responsibilities as well as their service and business model.

National workshops were organized in Finland, Sweden and Austria to define the roles and responsibilities of MaaS stakeholders. The participants varied in the workshops but all included a wide variety of key stakeholders (Table 2). The roles and responsibilities were based on a roadmap workshop defining short-term (1-3years) and medium-term (4-9 years) actions and transitions of MaaS. Actions and transitions were discussed in groups for drivers, markets, MaaS services and enablers, and the results were presented using Post-it notes on a large roadmap paper sheet. The Post-it notes were then organized by topic, and the groups discussed the responsible actor(s) for each topic and possibly other important stakeholders as well. Finally, the group work results on responsible actors were presented and set in order of priority by the participants. 


\section{Table 1. Interviewed organizations}

\begin{tabular}{|c|c|c|}
\hline \multicolumn{3}{|c|}{ Primary Stakeholders } \\
\hline \multirow{3}{*}{$\begin{array}{c}\text { National } \\
\text { authorities }\end{array}$} & $\begin{array}{l}\text { Ministry of Transport and Communications, } \\
\text { Finland }\end{array}$ & Finnish Transport Safety Agency, Finland \\
\hline & Ministry of Agriculture and Forestry, Finland & Finnish Transport Agency, Finland \\
\hline & ASFINAG, Austria & \\
\hline \multirow{7}{*}{$\begin{array}{l}\text { Local and } \\
\text { regional } \\
\text { authorities }\end{array}$} & $\begin{array}{l}\text { Centre for Economic Development, Transport and } \\
\text { the Environment of Lapland, Finland }\end{array}$ & $\begin{array}{l}\text { Centre for Economic Development, Transport } \\
\text { and the Environment of South Ostrobothnia, } \\
\text { Finland }\end{array}$ \\
\hline & $\begin{array}{l}\text { Centre for Economic Development, Transport and } \\
\text { the Environment of Southeast Finland }\end{array}$ & $\begin{array}{l}\text { Soite - Central Ostrobothnia joint municipal } \\
\text { authority of social and health service, Finland }\end{array}$ \\
\hline & Regional Council of Central Ostrobothnia, Finland & $\begin{array}{l}\text { South Karelia Social and Health Care District, } \\
\text { Finland }\end{array}$ \\
\hline & Regional Council of Lapland, Finland & The city of Hämeenlinna, Finland \\
\hline & Regional Council of South Karelia, Finland & The city of Imatra, Finland \\
\hline & Trafikkontoret, Gothenburg, Sweden & The city of Rovaniemi, Finland \\
\hline & Region of Västra Götaland, Sweden & \\
\hline \multirow{3}{*}{ MaaS operators } & MaaS Global, Finland & Ubigo Innovation, Sweden \\
\hline & Telia Company, Finland & Sito, Finland \\
\hline & Tuup, Finland & SNCF, France \\
\hline \multirow{7}{*}{$\begin{array}{l}\text { Service providers } \\
\quad \text { (transport, } \\
\text { logistics, digital) }\end{array}$} & Västtrafik public transport, Sweden & VR, Finland \\
\hline & ÖBB, Austria & Uber, Finland \\
\hline & Sunfleet carsharing, Sweden & Mobisoft, Finland \\
\hline & PayiQ, Finland & Municipality logistics of Finland \\
\hline & Siemens, Finland & Petri Pekkala (trade name), Finland \\
\hline & Tuomi Logistics Ltd., Finland & Posti Group Corporation, Finland \\
\hline & Tieto, Finland & \\
\hline \multicolumn{3}{|c|}{ Secondary Stakeholders } \\
\hline \multirow{4}{*}{ Academia } & Gothenburg University, Sweden & DLR, Germany \\
\hline & Trivector, Sweden & Victoria Swedish ICT, Sweden \\
\hline & ÅF Consulting, Sweden & Tampere University of Technology, Finland \\
\hline & Vinnova, Swedish innovation agency, Sweden & VTT Technical Research Centre of Finland Ltd. \\
\hline \multirow{7}{*}{$\begin{array}{l}\text { Other } \\
\text { stakeholders }\end{array}$} & Forum Virium Helsinki, Finland & $\begin{array}{l}\text { The social insurance institution of Finland } \\
\text { (Kela) }\end{array}$ \\
\hline & $\begin{array}{l}\text { Linna business development (Hämeenlinna), } \\
\text { Finland }\end{array}$ & Association of People with Disabilities, Finland \\
\hline & E-Mobility, Austria & $\begin{array}{l}\text { The Association of Finnish Local and Regional } \\
\text { Authorities, Finland }\end{array}$ \\
\hline & The council of rural policy MANE, Finland & Visit Rovaniemi, Finland \\
\hline & The hospital district of Lapland, Finland & Finnish Taxi, Finland \\
\hline & The hospital district of North Ostrobothnia, Finland & Growth Corridor Finland \\
\hline & Samtrafiken, Sweden & \\
\hline
\end{tabular}


Table 2. Stakeholders participating in the workshops

\begin{tabular}{|l|l|l|}
\hline \multicolumn{2}{|c|}{ Primary Stakeholders } & \multicolumn{1}{c|}{ Secondary Stakeholders } \\
\hline Ministries & $\begin{array}{l}\text { Transport agencies/ } \\
\text { Road administrations }\end{array}$ & Consultancy \\
\hline Infrastructure operators & Municipalities and cities & Academia \\
\hline Regional administrations & $\begin{array}{l}\text { Social and health care districts in } \\
\text { Finland }\end{array}$ & $\begin{array}{l}\text { The social insurance institution of } \\
\text { Finland (Kela) }\end{array}$ \\
\hline Public transport operators & Car sharing companies & Taxi union (Finland) \\
\hline Railway operator & Logistics operators & Bus union (Finland) \\
\hline MaaS operators & Technology providers & Funding agencies \\
\hline
\end{tabular}

Preliminary results were obtained by integrating and processing the collected data from the interviews and workshops in research group working meetings. Finally, the preliminary results were further developed, prioritized and validated in consolidation workshops. The participants in the consolidation workshops included representatives of national, regional and local authorities and institutions. Regarding roles and responsibilities, the results of the workshop and the first set of interviews were first integrated and validated in a European consolidation workshop. These results were further developed by the second set of interviews and then validated in a national consolidation workshop in Finland. The rural MaaS PPPP model was developed based on the interviews. The preliminary results including several potential rural MaaS network models were further developed based on group discussions in the Finnish consolidation workshop. The models were prioritized and the selected model validated.

\section{RURAL MAAS EXPERIENCES AND IMPLICATIONS}

So far, fully integrated MaaS services do not exist in Finnish rural areas. However, there are and have been pilots and services that include some aspects of integration (see Table 3).

Telia Company initiated the Ylläs Around PPP service pilot in the Ylläs ski resort area of Northern Finland in the spring of 2016. The second season of the pilot, winter 2016-17, was operated by Semel. Telia Company/Semel operated the service in cooperation with other main stakeholders comprising local transport operators, the Kolari local municipality, the Ylläs Travel Association and the Finnish Transport Agency. The main idea of the Ylläs Around pilot was to offer one-stop-shop transport services in the Ylläs ski resort area and between the Ylläs 
Table 3. Characteristics of rural MaaS pilots and services

\begin{tabular}{|c|l|l|l|l|l|l|l|}
\hline $\begin{array}{c}\text { Service (S) / } \\
\text { Pilot (P) Name }\end{array}$ & $\begin{array}{c}\text { Multimodal } \\
\text { Information }\end{array}$ & $\begin{array}{c}\text { Shared } \\
\text { Trip/ } \\
\text { Vehicle }\end{array}$ & $\begin{array}{c}\text { On- } \\
\text { Demand }\end{array}$ & $\begin{array}{c}\text { People } \\
\text { and } \\
\text { Goods }\end{array}$ & $\begin{array}{c}\text { Integrated } \\
\text { Modes or } \\
\text { Services }\end{array}$ & $\begin{array}{c}\text { Private and } \\
\text { Subsidized } \\
\text { Customers }\end{array}$ & $\begin{array}{c}\text { Ticketing/ } \\
\text { Mobile } \\
\text { Payment }\end{array}$ \\
\hline Ylläs Around (P) & $\mathrm{x}$ & $\mathrm{x}$ & $\mathrm{x}$ & & $\mathrm{x}$ & & $\mathrm{x}$ \\
\hline Lapin reittiopas (P) & $\mathrm{x}$ & & & & & & \\
\hline Matkahuolto (S) & & $\mathrm{x}$ & & $\mathrm{x}$ & $\mathrm{x}$ & & $\mathrm{x}$ \\
\hline ALPIO (P) & & $\mathrm{x}$ & $\mathrm{x}$ & & & $\mathrm{x}$ & $\mathrm{x}$ \\
\hline
\end{tabular}

area and the main local transport hubs Kittilä airport and Kolari railway station. The pilot included multimodal transport services available to end-users through a mobile application including payment and ticketing features. The transport modes on offer included buses, taxis, shared taxis and combinations of these. The original plan was to include freight/parcel deliveries, meal/food deliveries and snowmobiles in the future, but after financing for the pilot ended, Ylläs Around did not continue. Despite largely positive feedback from users and recognition of the pilot's future potential, the Ylläs Travel Association found it challenging to cover the expenses of the system with the achieved number of users (König et al., 2016a; Finnish Transport Agency, 2017).

In Finnish Lapland, the Open Arctic MaaS project (2018-2019) has developed a comprehensive digital search and trip planner, 'Lapin reittiopas', in collaboration with several municipalities, ski resorts and other actors. The aim is to improve the accessibility of sparsely populated Northern Finland and support sustainable growth of tourism at the same time. The trip planner provides real-time information on service alerts, vehicle positions and trip updates. This development is seen as an enabler for future MaaS integrating different mobility services. (Open Arctic MaaS, n.d.)

Matkahuolto is a company promoting bus and coach services in Finland. Its main business areas include Travel and Parcel Services. Travel Services develop and maintain nationwide timetables and an online store including the services of over 100 bus companies. Also, a mobile application is available for purchasing tickets and reserving seats among other features. Matkahuolto operates 50 terminals and service points, and through its partners nearly 2000 service points are available. It also offers different Parcel Services including a bus parcel option. Matkahuolto thus combines the transport of people and goods on buses covering nearly the whole country. (Matkahuolto, n.d.)

The ALPIO project includes a PPP pilot in rural areas of the Tampere region, which started in the spring of 2019. The pilot consists of demand-responsive transport, shared transport of different user groups and combining trips that include customers paying themselves and those being publicly subsidized. Thus, elderly and mobility 
impaired people using demand-responsive service transport (minibus) and health and social service clients using subsidized taxi services are integrated with selfpaying customers. Users paying for their own trips use a smartphone application to order a demand-responsive transport at a public transport fare. Primarily, self-paying customers are integrated with service transport minibus but may also be integrated with taxi rides when needed. A digital platform is created by companies participating in the project to optimize routes and integrate rides. A call center service is also available for subsidized customers. (The Finnish Innovation Fund Sitra, n.d.)

\section{PPPP Network}

Public-private collaboration is considered suitable especially for sparsely populated areas where public transport is limited or does not exist. Public actors bring in statutory and subsidized transport services that form the backbone of transport flows into which other transport services can be integrated. Public-private collaboration can take place in many forms and at many levels. Figure 2 proposes a conceptual model of a potential future PPPP network for MaaS based on interviews. It is targeted especially at rural areas, where integration of different transport solutions and private resources would increase efficiency and enable a wider variety of transport services.

The PPPP interface is based on a one-stop-shop principle. Customers would contact the same interface regardless of whether they are private customers paying for the services themselves or whether society is subsidizing the trips. Responsibility for operation of the interface could be assigned to a MaaS operator or split between a MaaS operator for market-based services and a transport service center for publicly subsidized services. In the latter case, tight collaboration would mean that for the customer there is still only a single interface.

Statutory transportation includes social and health service transportation, which refers e.g. to transportation of the elderly and handicapped, illness-related transportation, non-urgent medical transportation by hospital districts and school transportation. Homecare services refers to medical or non-medical services such as meal deliveries. The mobility solutions of homecare personnel are also relevant, not only product and meal deliveries. In addition to publicly subsidized transportation and homecare services, a transport service center could be responsible for logistics deliveries of the public sector, and for coordinating and combining these transportations.

A MaaS operator would be responsible for integrating market-based mobility services and potential additional services such as goods deliveries and activity services. Activity organizers could also offer mobility services as an additional service. Activity here refers to e.g. events such as concerts and sports games, tourist activities such as safaris and attraction visits, and leisure activities. 
Figure 2. PPPP network for MaaS

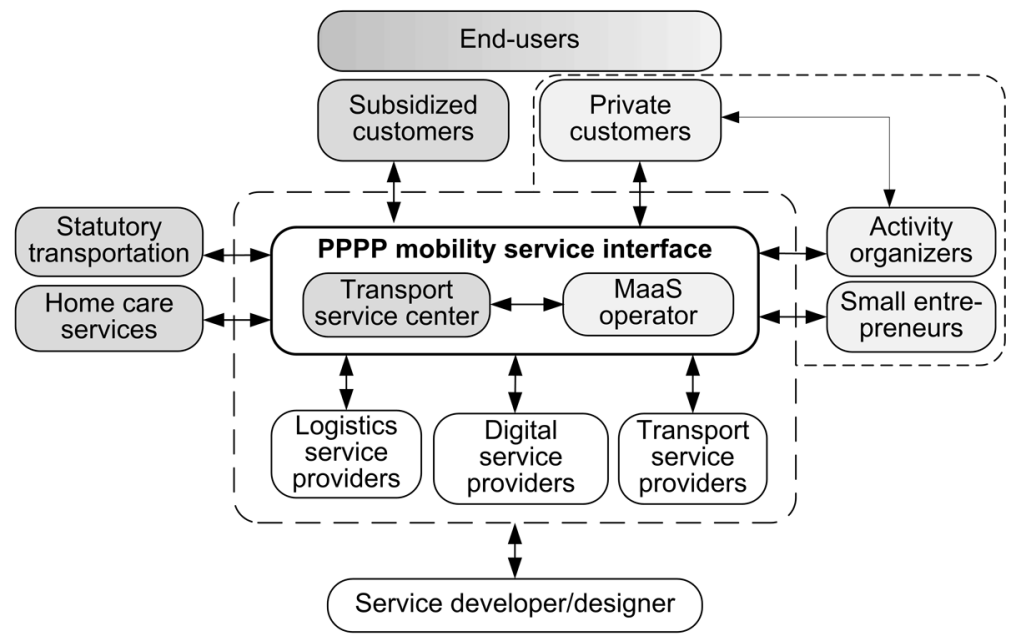

Transport service providers (TSP) would offer a variety of mobility services by different transport modes. These services could include public transport, sharing and rental services, ridesourcing, etc. The public transport offering in rural areas usually refers to buses. In cities it often includes also metros, trams, commuter trains and city bikes. In addition to traditional scheduled operation, demand-responsive transport (DRT) is increasingly receiving attention.

Logistics service providers (LSP) would offer transport services for both the public and private sectors. Small enterprises could use, but also offer, logistics/ mobility services in addition to their core business. Especially in rural areas with low utilization rates, free capacity could be offered through the PPPP mobility service interface. If national legislation allows, transportation of people and goods could be combined, for example, by taxis and buses. Also, vans and trucks could offer taxi services while transporting freight.

Private people, activity organizers and small enterprises can be considered as both customers and mobility service providers. Transport services could also be provided by shared private resources, bringing the 'people' aspect into this publicprivate-people partnership (PPPP or 4P) network. Shared private resources would integrate e.g. peer-to-peer rental services, carpooling and organized hitchhiking with the MaaS service offering. Private people could also provide ridesharing services for goods on a crowdsourcing basis.

Digital service providers (DSP) offer information and communication technology (ICT) solutions such as mobility applications for smartphones. ICT is also required for the demand-responsive transport service system, and to ensure interoperability 
and integration of travel chains and different user groups. Mobility applications would include multimodal journey planners, booking, mobile ticketing and payment. Also real-time data (e.g. real-time bus locations) and deviation and rerouting information could be provided. Although smartphones and mobile applications are becoming increasingly common, call services should also be available at least for special groups.

The service developer/designer would ensure that mobility services and user interfaces are user-friendly and customer-oriented. Optimally, the user interface would be easy to use and have the intelligence to guide the user to find fit-forpurpose solutions, avoid mistakes and minimize typing errors, e.g. by providing options to select.

\section{Stakeholder Roles and Responsibilities}

MaaS aims to integrate all transport modes and services. To achieve this at operational level, interoperability and collaboration must be achieved at higher levels also. Thus, the various roles and responsibilities of MaaS stakeholders within the emerging MaaS ecosystems are essential to ensuring this process. A MaaS ecosystem consists of primary stakeholders on four levels: 1) public and regulatory level; 2) transport and logistics service provider level (i.e. supply side, including mobile/ICT service providers); 3) mobility service level ('a MaaS operator') and 4) end-user level (Aapaoja et al., 2017). In addition, there are secondary stakeholders involved. Table 4 lists the primary and some secondary stakeholders and their roles and responsibilities. However, the roles may vary between countries, which should be considered when interpreting these for a specific country context. For example, some countries do not have tolling, and the division of responsibilities between different authorities may vary.

National road authorities, ministries and government are responsible for the operational environment for MaaS trough policy and regulation, and hence have a role as MaaS enablers. They create incentives and disincentives for MaaS, sustainable transport policy and new technological infrastructure, and allocate investments accordingly. They also prepare regulations and rules that can promote MaaS development. This may refer e.g. to reregulation of rules hindering MaaS implementation and opening up transport data. National regulations are partly based on EU regulations. European Commission Member States are setting up their National Access Points to "facilitate access, easy exchange and reuse of transport related data, in order to help support the provision of EU-wide interoperable travel and traffic services to end users" (European Commission, 2019). Regulations should 
Public-Private-People Partnership Networks and Stakeholder Roles Within MaaS Ecosystems

\section{Table 4. Roles and responsibilities of stakeholders within MaaS ecosystems}

\begin{tabular}{|c|c|c|}
\hline Level & Stakeholder & Roles and Responsibilities \\
\hline \multicolumn{3}{|r|}{ Primary Stakeholders } \\
\hline \multirow{4}{*}{$\begin{array}{l}\text { National } \\
\text { authorities }\end{array}$} & Government & National incentives and subsidies; legislation processes \\
\hline & Ministries & $\begin{array}{l}\text { Legislator; transport policy and strategies; infrastructure investments; } \\
\text { funding }\end{array}$ \\
\hline & Road authorities & $\begin{array}{l}\text { Implementation of transport policy, strategy and investments; open transport } \\
\text { data; permits; licenses; collaboration }\end{array}$ \\
\hline & $\begin{array}{l}\text { Infrastructure } \\
\text { operator }\end{array}$ & Road network operations; tolling \\
\hline \multirow{3}{*}{$\begin{array}{l}\text { Local and } \\
\text { regional } \\
\text { authorities }\end{array}$} & $\begin{array}{l}\text { Regional transport } \\
\text { agency }\end{array}$ & Regional public transport; locations of stations and stops \\
\hline & Regional government & Land use planning; strategic planning and development \\
\hline & $\begin{array}{l}\text { Municipalities and } \\
\text { cities }\end{array}$ & $\begin{array}{l}\text { Transportation and traffic planning; municipal public transport; statutory } \\
\text { transportation }\end{array}$ \\
\hline \multirow{6}{*}{$\begin{array}{l}\text { Transport service } \\
\text { providers }\end{array}$} & $\begin{array}{l}\text { Municipal public } \\
\text { transport }\end{array}$ & Schedules, ticketing and real-time information \\
\hline & $\begin{array}{l}\text { Long-haul public } \\
\text { transport }\end{array}$ & Schedules, booking, ticketing and real-time information \\
\hline & Bike sharing & Fares, locations and availability \\
\hline & Car services & Fares, vehicle information, booking information, availability, locations \\
\hline & Ride sharing & Drivers and rides platform \\
\hline & Taxi & Fares, vehicle information, booking information \\
\hline $\begin{array}{l}\text { Logistics service } \\
\text { providers }\end{array}$ & Logistics operators & $\begin{array}{l}\text { Management of material flows between points of origin to end-use } \\
\text { destination }\end{array}$ \\
\hline $\begin{array}{l}\text { Digital service } \\
\text { providers }\end{array}$ & $\begin{array}{l}\text { ICT and mobile } \\
\text { service providers }\end{array}$ & $\begin{array}{l}\text { Key enabling technology solutions, services and applications to MaaS } \\
\text { operators and service providers }\end{array}$ \\
\hline MaaS operators & $\begin{array}{l}\text { MaaS company, } \\
\text { public transport } \\
\text { operator, PPP etc. }\end{array}$ & $\begin{array}{l}\text { Combine existing transport services on the 'one-stop-shop' principle; } \\
\text { customer service; service offering; service level; business model }\end{array}$ \\
\hline Users & Citizens, customers & Communicate user needs and feedback; provide services ('prosuming') \\
\hline \multicolumn{3}{|r|}{ Secondary Stakeholders } \\
\hline Funding agencies & $\begin{array}{l}\text { Private, public and } \\
\text { R\&D\&I }\end{array}$ & Financial support and risk capital \\
\hline $\begin{array}{l}\text { OEMs and } \\
\text { Resellers }\end{array}$ & Automotive industry & Fleet; technology; servitization \\
\hline Academia & $\begin{array}{l}\text { Universities, research } \\
\text { institutes }\end{array}$ & $\begin{array}{l}\text { Evaluation and impact assessment; new trends and knowledge; } \\
\text { recommendations }\end{array}$ \\
\hline $\begin{array}{l}\text { Insurance } \\
\text { companies }\end{array}$ & $\begin{array}{l}\text { Private and business } \\
\text { insurances }\end{array}$ & New insurances for MaaS \\
\hline
\end{tabular}


also ensure transparent and fair market conditions and competition. As indicated in Table 4, several stakeholders are involved in MaaS. Road authorities could promote collaboration between different stakeholders and transport modes towards common goals of MaaS.

Authorities also issue permits and licenses. These include basic permits and licenses for transport operators and drivers, but also for new trials of automated and robotized vehicles. The infrastructure operator is responsible for planning, constructing and maintaining the road infrastructure as well as tolling. Based on bilateral agreements, MaaS services may include special offers for tolling. In France, for example, SNCF's iDVROOM carpooling service offers a free automatic toll badge, no management costs, and a monthly downloadable invoice for their clients (iDVROOM, 2019).

National regulations and policy, including sustainability goals and incentives, are implemented by local and regional authorities at regional and municipal levels. Regions within a country may also be called e.g. counties, provinces and cantons. Local and regional authorities are responsible for transport planning, regional and municipal public transport and land use, as well as for creating preconditions for business. They are also responsible for organizing statutory transportation. This refers e.g. to school transportation, social and health service transportation and home care services. New and innovative public procurement processes enable organizing and combining different statutory transportation and public transport, which is especially important in sparsely populated areas. The role of local and regional authorities may strengthen in the future as they play a strategic role in a PPP MaaS ecosystem and even as a MaaS operator.

Local and regional authorities are responsible for opening public transport interfaces and data to enable travel chains and digital services. They provide locations of stations and stops, as well as stop names. Digital services use bus-stop names indicated by the authorities, which should therefore avoid misleading names and preferably use names that describe the location well.

Transport service providers include different transport modes and various services, including sharing and rental services. All TSPs are responsible for offering quality services, customer service and a good user experience of their own services. They also need to open data and Application Programming Interfaces (APIs) to enable reselling and integration of various services. In addition, every TSP is responsible for providing relevant information to its users; for e.g. public transport this includes schedules, fares and ticketing and real-time information. Long-haul buses and rail would also provide booking information. For car sharing and rental services, locations and availability of vehicles is important, as is docking station information for bike sharing. For ride sharing, a data platform for drivers and rides is essential to identify registered users and to match demand and supply. This also applies to on-demand 
transport. Taxis are increasingly using mobile applications and are part of the MaaS service offering. They provide fares, vehicle information and booking information.

Logistics service providers provide management of material flows. This may include, in addition to transportation, other logistics services such as warehousing and packaging. Logistics is seen as an add-on service to MaaS, not a primary operation. However, it is important to combine flows of people and goods when relevant to gain e.g. efficiency in rural areas.

Digital service providers are responsible for providing key enabling technology, services and applications to MaaS operators and transport service providers. This refers e.g. to mobile ticketing and payment, information and data services as well as different platforms, databases and open interfaces such as APIs. DSPs can also utilize intelligent and connected infrastructure (also known as C-ITS) as a MaaS element. DSPs offer technology services that enable MaaS and thus the integration of different services, travel chains, on-demand transport and the one-stop-shop principle. DSPs also provide the end-user interface, which is important for the user experience and perceived ease of the service.

The role of MaaS operator is a new take on traditional transport services and holds a key position. It is responsible for the service offering, business model, bilateral agreements with different service providers, and for combining services on a one-stop-shop principle. The MaaS operator is responsible for the service level of the entity of services offered. It can be a MaaS company for which MaaS is the main business - such MaaS Global which provides e.g. the Whim service in Helsinki - or a company for which it is a secondary business supporting the company's primary business. The public transport operator may also act as a MaaS operator. Thus, traditional public transport services are being complemented by new additional services. A good example is SNCF, the French national railway company, which proposes several first and last mile services to create the entire travel chain for their customers. In addition, municipal or regional public transport operators may complement their service offering with e.g. city bikes and shared vehicles. The PPP MaaS operator is considered suitable especially for sparsely populated areas where market-based solutions are not viable and different types of transport need to be combined to increase efficiency.

Users, aside from using MaaS services, are also expected to give feedback and communicate their needs in order to promote the development of the services. Users are also involved as 'prosumers', consuming and producing services and sharing their resources on a collaborative economy basis. Users could, for example, offer peer-to-peer carsharing and ride sharing of people and goods. Thus, PPP could be further developed into a PPPP model including the 'people' aspect. This is in line 
with the Swedish definition of public transport as 'passenger transport services by shared resources' (Laurell, 2017).

Secondary stakeholders support MaaS but not in a critical role. These include e.g. funding agencies, original equipment manufacturers (OEM) and resellers, academia and insurance companies. Funding agencies, including innovation and research funding, include both public and private agencies that provide financial support and risk capital for MaaS business solutions. As MaaS is a new concept requiring new business models, and consumer habits change slowly, time, persistence and funding are needed for an extensive MaaS implementation. Thus, funding opportunities are important for MaaS actors.

OEMs and resellers produce a sustainable fleet for MaaS, such as electric vehicles (EV). They also create new technology, for example keyless systems for shared vehicles. They promote new business models and servitization by participating in the development of new services such as car sharing, rental and leasing services.

Academia and research organizations provide neutral and valuable new information regarding e.g. trends and evaluation of MaaS. Impact assessment of MaaS services and pilots is needed to identify the potential impacts of MaaS on business, user and societal levels and the entire transport system. Research results and recommendations assist decision- and policy-makers and other stakeholders. Research also brings information and communication to the public about new developments and helps create trust in new transport services.

Insurance companies develop new insurance services for MaaS in collaboration with service providers, such as sharing, rental, peer-to-peer and ridesharing services. As an example, the peer-to-peer car rental service Blox Car offers, in collaboration with an insurance company, an insurance where there is no bonus loss in case of an accident during the rental period (Blox Car, n.d.). The French ride sharing company BlaBlaCar proposes a car insurance where clients can benefit from sharing rides (BlaBlaCar, n.d.).

\section{DISCUSSION}

MaaS is a new emerging concept with multiple stakeholders and a complex ecosystem. In these early stages, several pilots and some services already exist but tend to be restricted to limited geographical areas or transport modes or to a small number of mobility services. The level of integration is also generally quite low, and many existing services could be considered MaaS-related due to their low integration level. Broad ecosystems with PP(P)P involvement do not yet exist, thus there is no evidence of how they would work out, but the $\mathrm{PP}(\mathrm{P}) \mathrm{P}$ model is expected to have 
several benefits and pilots and development are underway towards this kind of collaboration.

The results of the conceptual PPPP network model and stakeholder roles and responsibilities are derived from qualitative data based on the knowledge and experience of experts representing different stakeholders of the MaaS ecosystem. The results are comprehensive, but may not cover all essential aspects, especially due to the early stages of MaaS and limited experience. Also, future MaaS development will show the applicability of the results. At the moment, PPP MaaS pilots are underway in Finland, and shared resources are seen as a vital part of future public transport in Sweden, supporting these results. Even though the results are based on work mainly with Finnish stakeholders and partly with experts from other European countries (e.g. Sweden and Austria), the results are also relevant and applicable to other countries. For example, in the U.S., similar stakeholders to those listed in Table 4 have been identified related to the Mobility on Demand (MOD) concept (Shaheen, Cohen, Yelchuru, \& Sarkhili, 2017). However, countries and rural areas even within the same country have differences and specific characteristics, which should be considered when interpreting the results. For example, in Finland, data network coverage is comprehensive also in rural areas, enabling the widespread use of digital services. Internationally, Finland is leading the way in mobile data usage (see e.g. McCarthy, 2017). In some countries, inadequate data network coverage may limit digital service deployment, especially in rural areas.

The vision is to see the whole transport sector as a cooperative, interconnected ecosystem, providing services based on the needs of stakeholders, especially customers, and seamlessly combining different transport modes such as private vehicles, public and collective transport, biking and walking (Eckhardt et al., 2017a). This requires a general understanding of the roles and responsibilities of each ecosystem stakeholder. In addition to understanding, actions need to occur. Despite the definition of roles, it is not always obvious which stakeholder takes responsibility for holistic MaaS development and implementation. Public stakeholders might create better preconditions, for instance through regulation, and expect the business sector then to lead the development. However, in the early stages MaaS usually requires financial support even in cities. In addition, the responsibility for MaaS development might be shunted between authorities. If large and sustainable MaaS ecosystem development is pursued, the public sector has to take a strong role and lead the integration of public and private collaboration.

The public sector could start their mobility service development by digitalizing transport data and integrating and rationalizing public and statutory transport services. In sparsely populated areas, this might mean the use of demand-responsive transport and combining different user groups as well as people and goods. Later on, more services could be integrated, such as commercial and shared mobility services. 
Municipalities could also collaborate to increase efficiency and learn from each other. Public procurement defines the preconditions for transport services. Procurement of new mobility services is challenging and needs further research in order to propose good practices and guidance regarding collaboration models, innovative procurement and ensuring technological openness and scalability.

The PPP and PPPP models can potentially reduce emissions, bring remarkable cost savings to the public sector and huge benefits to users. More personalized mobility services could help attract new customers by facilitating door-to-door transport. The benefits of a PP(P)P network could be more remarkable in rural areas where the transport service offering is usually limited. Rural areas could be more vital and accessible when integrating subsidized transport and shared private resources with market-based mobility services. This kind of integration would bring more variety to the service offering and better use of available vehicle capacity.

Shared and integrated mobility services require technology and digitalization. It is challenging currently to get all the relevant actors of the MaaS ecosystem to digitalize their transport data in order to enable interoperability. Also, as mentioned previously, data network coverage may hinder the development of MaaS especially in rural areas. Other possible challenges are dependency on the public sector's resources, skills and willingness to develop MaaS and procure new services. Bringing in the people aspect may also cause challenges. It is uncertain to what extent people are willing to adopt these services, both as producers and consumers. Also, if the service offering in rural areas depends a lot on prosumers offering e.g. ridesharing, peer-to-peer carsharing and organized hitchhiking, the provision of services might be occasional, and a sufficient service offering may not be guaranteed at all times.

Due to the potential benefits of the PPPP model, it will be likely introduced in rural areas in the near future. Like other MaaS pilots and services, it will probably start only with limited geographical areas and services. The speed and success of large-scale implementation is uncertain. Even though public-private collaboration is expected to become increasingly popular in cities too, in rural areas PPP is a necessity. In cities, it is possible for the business sector to offer viable services without public involvement. However, PPP is also beneficial in cities for the integration of city policies with mobility services.

More research on PPP and PPPP models is needed in relation to both MaaS in rural areas and cities. As users usually change their behavior slowly, it should be ensured that the duration of the pilots is long enough. Otherwise, it could be falsely concluded that there is not enough demand for new mobility services, as users have not had time to adopt new habits. Marketing of new pilots and services is important in order to raise awareness of new services. Marketing is also essential to have enough users to obtain reliable and possibly encouraging results for the continuation of services. Based on pilots and other MaaS experiences, good practices 
should be widely disseminated and scaled to other areas and more extensive service integration. Impact assessments of PP(P)P MaaS services should be performed to assist decision-making.

\section{CONCLUSION}

This chapter set out to explore potential PPPP networks for rural mobility and the stakeholders involved in MaaS ecosystems. A PPPP model was proposed which combines market-based and subsidized transport services on a one-stop-shop principle. Due to long distances, sparse population and low utilization and occupancy rates of vehicles in rural areas, combining different mobility services of people and goods, as well as user groups, is crucial to improving efficiency and enabling viable services. Public actors may combine various types of stakeholders and services in a MaaS system, which can rationalize the services on public actors' responsibility, e.g. statutory social and health service transportation and freight/delivery. Public actor involvement is required where market-based public transport and other transport services are not viable. Statutory transport services and shared private resources form a basis for mobility services in sparsely populated areas. Thus, the PPPP model has huge potential for future rural mobility. The involvement of public actors will likely lead to integration of societal goals and thus could take MaaS to the highest level of integration according to the classification of Sochor et al. (2018). This classification does not take freight into account. The mobility of goods can be considered similar to the mobility of people in the classification, except that rural MaaS can be more a matter of combining different services and user groups than modes, since accessibility is the key concern for people and services regarding MaaS. Rural MaaS could be defined as mobility of people and goods on a one-stop-shop principle consisting of various user groups and integrated transport services.

Twenty stakeholders were identified in MaaS ecosystems, of which sixteen are primary stakeholders and four are secondary stakeholders. As primary stakeholders are crucial for business, it can be concluded that MaaS is a complex system requiring collaboration of a large number of stakeholders in order to create extensive and integrated MaaS. Primary stakeholders are authorities, service providers, MaaS operators and users. They all have an important role and they should be aware of their roles and interaction between stakeholders. Authorities create preconditions for MaaS by setting legislation, regulations and incentives to better enable new mobility services. The MaaS operator is a new player, who in collaboration with service providers integrates a variety of services to offer them on a one-stop-shop principle. The role of the MaaS operator is crucial, as it in the last resort determines how attractive MaaS services are for users. The MaaS operator designs the service 
offering, e.g. services included, geographical coverage, pricing, payment system (subscription/pay-as-you-go) and user interface. It could be considered that good quality MaaS services are enough to boost MaaS. However, some curiosity and flexibility are required from users to change their behavior and try new services. Especially in rural areas where the mobility service offering is poor, users can also have a remarkable role as prosumers (producer and consumer) by offering e.g. peer-to-peer, carpooling and organized hitchhiking services. Secondary stakeholders are also important for promoting MaaS e.g. by enabling financing, developing new service components and providing information for decision- and policy-making.

The future of MaaS is uncertain, as MaaS is in its early stages. Regardless of how the MaaS concept will develop, features for future mobility include collaboration on various levels, implementing new mobility services and utilizing digitalization. These new services refer to e.g. travel chains, demand-responsive transport, carpooling/ ridesharing, sharing services (car, bike, scooter...), peer-to-peer rental services, shared taxi rides, ridesourcing/ridehailing, organized hitchhiking, and combining the mobility of people and goods, as well as combining publicly subsidized and market-based transport services. Digitalization is the key to integrating different transport services, and the transport sector is actively promoting digital open data, open interfaces and other technological development. Above all, integrated MaaS services require collaboration between relevant stakeholders in the MaaS ecosystem, even between rivals.

\section{ACKNOWLEDGMENT}

This research was supported by the Conference of European Directors of Roads (CEDR) Transnational Road Research Programme and the Development Fund of the Ministry of Agriculture and Forestry of Finland. The authors gratefully acknowledge the funding organizations and researchers contributing to the projects. 


\section{REFERENCES}

Aapaoja, A., Eckhardt, J., Nykänen, L., \& Sochor, J. (2017). MaaS service combinations for different geographical areas. Proceedings of the 24th World Congress on Intelligent Transportation Systems.

Aapaoja, A., \& Haapasalo, H. (2014). A framework for stakeholder identification and classification in construction projects. Open Journal of Business and Management, 2(1), 43-55. doi:10.4236/ojbm.2014.21007

Adner, R. (2006). Match your innovation strategy to your innovation ecosystem. Harvard Business Review, 84(4), 98-107. PMID:16579417

BlaBlaCar. (n.d.). BlaBlaCar Une nouvelle façon d'économiser grâce à votre assurance auto. Retrieved from https://assurance.blablacar.fr/

Blox Car. (n.d.). Blox Car How it works. Retrieved from https://bloxcar.fi/how-it-works

Burrows, A., Bradburn, J., \& Cohen, T. (2015). Journeys of the Future. Introducing Mobility as a Service. London: Atkins.

Clark, B., Chatterjee, K., \& Melia, S. (2016). Changes in level of household car ownership: The role of life events and spatial context. Transportation, 43(4), 565-599. doi:10.100711116-015-9589-y

Clarkson, M. B. E. (1995). A Stakeholder Framework for Analyzing and Evaluating Corporate Social Performance. Academy of Management Review, 20(1), 92-117. doi:10.5465/amr.1995.9503271994

Cleland, D. I. (1986). Project stakeholder management. Project Management Journal, 17(4), 36-44.

Eadie, R., Millar, P., \& Toner, L. (2013). Public private partnerships, reevaluating value for money. International Journal of Procurement Management, 6(2), 152-169. doi:10.1504/IJPM.2013.052467

Eckhardt, J., Aapaoja, A., Nykänen, L., Sochor, J., Karlsson, M., \& König, D. (2017a). Deliverable 2: European MaaS Roadmap 2025. MAASiFiE project funded by CEDR. Retrieved from https://www.vtt.fi/sites/maasifie/PublishingImages/results/ cedr_mobility_MAASiFiE_deliverable_2_revised_final.pdf 
Eckhardt, J., Nykänen, L., Aapaoja, A., \& Niemi, P. (2017b). Liikkumispalvelut maaseudun elinvoimaisuuden ja saavutettavuuden mahdollistajana [Mobility as a Service as an enabler for vitality and accessibility of rural areas]. VTT research report VTT-R-03429-17. Retrieved from https://www.vtt.fi/sites/maaseutumaas/ Documents/MaaseutuMaaS_raportti_revised_final2.pdf

Eckhardt, J., Nykänen, L., Aapaoja, A., \& Niemi, P. (2018). MaaS in rural areas - case Finland. Research in Transportation Business \& Management, 27, 75-83. doi:10.1016/j.rtbm.2018.09.005

Eesley, C., \& Lenox, M. J. (2006). Firm Responses to Secondary Stakeholder Action. Strategic Management Journal, 27(8), 765-781. doi:10.1002mj.536

ERTICO. (2018). Mobility as a Service -from modes to mobility. Brussels: ERTICO. Retrieved from https://ertico.com/wp-content/uploads/2018/09/Ertico_MaaS-visionpaper-2018_www.pdf

European Commission. (2016). A European Strategy for Low-Emission Mobility (COM(2016) 501 final). Brussels: European Commission.

European Commission. (2017a). An agenda for a socially fair transition towards clean, competitive and connected mobility for all (COM(2017) 283 final). Brussels: European Commission.

European Commission. (2017b). Smart, green and integrated transport, Horizon 2020 work programme 2016-2017. Retrieved from https://ec.europa.eu/research/ participants/data/ref/h2020/wp/2016_2017/main/h2020-wp1617-transport_en.pdf

European Commission. (2019). National Access Points. Retrieved from https:// ec.europa.eu/transport/themes/its/road/action_plan/nap_en

European PPP Expertise Centre. (2015). PPP Motivations and Challenges for the Public Sector. Luxembourg: European Investment Bank.

European PPP Expertise Centre. (2018). Market Update. Review of the European PPP Market in 2017. Luxembourg: European Investment Bank.

European Union. (2018). Public Private Partnerships in the EU: Widespread shortcomings and limited benefits (Special reportNo 9/2018). Luxembourg: European Court of Auditors.

Finnish Transport Agency. (2017). Ylläs Around impact study (in Finnish). Research reports of the Finnish Transport Agency 31/2017. Helsinki: Finnish Transport Agency. 
Freeman, E. R. (1984). Strategic Management: A Stakeholder Approach. New York, NY: Pitman Publishing Inc.

Håkansson, H., \& Johanson, J. (1992). A model of industrial networks. In B. Axelsson \& G. Easton (Eds.), Industrial Networks: A New View of Reality (pp. 28-34). London: Routledge.

Hallock, L., \& Inglis, J. (2015). The Innovative Transportation Index: The Cities Where New Technologies and Tools Can Reduce Your Need to Own a Car. Frontier Group.

Harms, L., Durand, A., Hoogendoorn-Lanser, S., \& Zijlstra, T. (2018). Exploring Mobility-as-a-Service: Insights from Literature and Focus Group Meetings. Den Haag: Ministry of Infrastructure and Water Management.

Heikkilä, S. (2014). Mobility as a Service - A Proposal for Action for the Public Administration: Case Helsinki (Master's Thesis). Retrieved from Aaltodoc database: http://urn.fi/URN:NBN:fi:aalto-201405221895

Hietanen, S. (2014). 'Mobility as a Service' - the new transport model? ITS \& Transport Management Supplement. Eurotransport, 12(2), 2-4.

Iansiti, M., \& Levien, R. (2004). Strategy as ecology. Harvard Business Review, 82(3), 68-78. PMID:15029791

International Transport Forum.(2015). International Experiences on Public Transport Provision in Rural Areas. Paris: International Transport Forum.

iVDROOM. (2019). iVDROOM Télépéage offert. Retrieved from https://lp.idvroom. com/telepeage-gratuit-covoiturage/

Jin,Z. R., \& Qiu, A.Z. (2019). Mobility-as-a-Service (MaaS) Testbed as an Integrated Approach for New Mobility - A Living Lab Case Study in Singapore. In H. Krömker (Ed.), HCI in Mobility, Transport, and Automotive Systems (pp. 441-458). Cham: Springer; doi:10.1007/978-3-030-22666-4_32

Jittrapirom, P., Caiati, V., Feneri, A.-M., Ebrahimigharehbaghi, S., Alonso-González, M. J., \& Narayan, J. (2017). Mobility as a Service: A Critical Review of Definitions, Assessments of Schemes, and Key Challenges. Urban Planning, 2(2), 13-25. doi:10.17645/up.v2i2.931

Kamargianni, M., Li, W., \& Matyas, M. (2016). A Comprehensive Review of "Mobility as a Service" Systems. Transportation Research Board 95th Annual Meeting 2016, 16-5401. 
Karlsson, M., Sochor, J., Aapaoja, A., Eckhardt, J., \& König, D. (2017). Deliverable 4: Impact Assessment. MAASiFiE project funded by CEDR.

Kinnunen, T., Aapaoja, A., \& Haapasalo, H. (2014). Analysing internal stakeholders' salience in product development. Technology and Investment, 5(2), 106-115. doi:10.4236/ti.2014.52011

König, D., Eckhardt, J., Aapaoja, A., Sochor, J., \& Karlsson, M. (2016a). Deliverable 3: Business and operator models for MaaS. MAASiFiE project funded by CEDR. Retrieved from https://www.vtt.fi/sites/maasifie/PublishingImages/results/cedr_ mobility_MAASiFiE_deliverable_3_revised_final.pdf

König, D., Sochor, J., Eckhardt, J., \& Böhm, M. (2016b). State-of-the-art survey on stakeholders' expectations for Mobility-as-a-Service (MaaS). In Proceedings of the 23rd World Congress on Intelligent Transport Systems. Melbourne: ITS Australia.

Laurell, A. (2017). Swedish Mobility Program (SMP): Den avslutande rapporten för projektet Vitt papper och samtidigt ett förarbete till Swedish Mobility Program $(S M P)$. Samtrafiken.

Leviäkangas, P., Aapaoja, A., Kinnunen, T., Pilli-Sihvola, E., Hautala, R., \& Zulkarnain, Z. (2014). The Finnish road weather business ecosystem: Turning societal benefits into business and the other way round. Engineering Management Research, 3(1), 56-67. doi:10.5539/emr.v3n1p56

Li, B., Akintoye, A., Edwards, P., \& Hardcastle, C. (2005). Perceptions of positive and negative factors influencing the attractiveness of PPP/PFI procurement for construction projects in the UK: Findings from a questionnaire survey. Engineering, Construction, and Architectural Management, 12(2), 125-148. doi:10.1108/09699980510584485

Lyons, G., Hammond, P., \& Mackay, K. (2019). The importance of user perspective in the evolution of MaaS. Transportation Research A. Policy \& Practice, 121, 22-36. doi:10.1016/j.tra.2018.12.010

MaaS Alliance. (2017). White paper. Guidelines \& Recommendations to Create the Foundations for a Thriving MaaS Ecosystem. Brussels: MaaS Alliance.

MAASiFiE. (2016). About MaaS concept and MAASiFiE project. Retrieved from http://www.vtt.fi/sites/maasifie/

Majamaa, W. (2008). The 4th P - People - in Urban Development Based on PublicPrivate-People Partnership (Doctoral dissertation). Retrieved from Aaltodoc database: http://urn.fi/URN:ISBN:978-951-22-9585-2 
Marana, P., Labaka, L., \& Sarriegi, J. M. (2018). A framework for public-privatepeople partnerships in the city resilience-building process. Safety Science Part $C$, 110, 39-50. doi:10.1016/j.ssci.2017.12.011

Matkahuolto. (n.d.). Retrieved from: https://matkahuolto.fi/

McCarthy, N. (2017). Mobile Data Subscriptions: Which countries use the most gigabytes? Forbes, 11(10), 2017. Retrieved from https:/www.forbes.com/sites/ niallmccarthy/2017/10/11/mobile-data-subscriptions-which-countries-use-the-mostgigabytes-infographic/\#2fd00e997220

Moore, J. F. (1993). Predators and prey: A new ecology of competition. Harvard Business Review, 71(3), 75-86. PMID:10126156

National Academies of Sciences, Engineering, and Medicine. (2016). Shared Mobility and the Transformation of Public Transit. Washington, DC: The National Academies Press. doi:. doi:10.17226/23578

Open Arctic MaaS. (n.d.). Retrieved from: https://www.arcticmaas.fi/

Organisation for Economic Cooperation and Development. (2012). Recommendation of the Council on Principles for Public Governance of Public-Private Partnerships. OECD.

Peltoniemi, M., \& Vuori, E. (2004). Business ecosystem as the new approach to complex adaptive business environments. In Proceedings of eBRF 2004. Tampere, Finland: Tampere University of Technology and University of Tampere.

Polis. (2017). Mobility as a Service: Implications for Urban and Regional Transport. Brussels: Polis.

Rezo Pouce. (n.d.). Rezo Pousse Médias et Presse. Retrieved from https://www. rezopouce.fr/page/Medias_et_Presse

Rubenstein-Montano, B., Liebowitz, J., Buchwalter, J., McCaw, D., Newman, B., \& Rebeck, K. (2001). A systems thinking framework for knowledge management. Decision Support Systems, 31(1), 5-16. doi:10.1016/S0167-9236(00)00116-0

Särkijärvi, J., Jääskeläinen, S., \& Lohko-Soner, K. (Eds.). (2018). Action programme for carbon-free transport 2045: Final report by the Transport Climate Policy working group (Publications of the Ministry of Transport and Communications, 13/2018). Helsinki: Ministry of Transport and Communications of Finland. 
Shaheen, S., Cohen, A., Yelchuru, B., \& Sarkhili, S. (2017). Mobility on Demand Operational Concept Report. Washington, DC: U.S. Department of Transportation. Retrieved from https://rosap.ntl.bts.gov/view/dot/34258

Shaheen, S., Cohen, A., \& Zohdy, I. (2016). Shared Mobility: Current Practices and Guiding Principles. Washington, DC: U.S. Department of Transportation.

Smith, G., Sarasini, S., Karlsson, I. C. M., Mukhtar-Landgren, D., \& Sochor, J. (2019a). Governing Mobility-as-a-Service: Insights from Sweden and Finland. In M. Finger \& M. Audouin (Eds.), The Governance of Smart Transportation Systems. Cham: Springer. doi:10.1007/978-3-319-96526-0_9

Smith, G., Sochor, J., \& Karlsson, I. C. M. (2019b). Public-private innovation: Barriers in the case of mobility as a service in West Sweden. Public Management Review, 21(1), 116-137. doi:10.1080/14719037.2018.1462399

Sochor, J., Arby, H., Karlsson, M., \& Sarasini, S. (2018). A topological approach to Mobility as a Service: A proposed tool for understanding requirements and effects, and for aiding the integration of societal goals. Research in Transportation Business \& Management, 27, 3-14. doi:10.1016/j.rtbm.2018.12.003

Sochor, J., Karlsson, M., \& Strömberg, H. (2016). Trying Out Mobility as a Service: Experiences from a Field Trial and Implications for Understanding Demand. Transportation Research Record: Journal of the Transportation Research Board, 2542(1), 57-64. doi:10.3141/2542-07

The Finnish Innovation Fund Sitra. (n.d.). Public and private mobility services to be offered side by side. Retrieved from https://www.sitra.fi/en/projects/public-privatemobility-services-offered-side-side/\#what-is-it-about

Transport Systems Catapult. (2016). Exploring the opportunity for Mobility as a Service in the UK. Milton Keynes, UK: Transport Systems Catapult.

Van Ham, H., \& Koppenjan, J. (2001). Building Public-Private Partnerships: Assessing and managing risks in port development. Public Management Review, 3(4), 593-616. doi:10.1080/14616670110070622

Whim. (n.d.). Whim Find your plan. Retrieved from https://whimapp.com/plans/

Winch, G. M., \& Bonke, S. (2002). Project stakeholder mapping: analyzing the interest of project stakeholders. In D. P. Slevi, D. I. Cleland, \& J. K. Pinto (Eds.), The frontiers of project management research. Newton Square Pennsylvania. Project Management Institute. 
Yin, R. K. (2003). Case Study Research: Design and Methods (3rd ed.). Beverly Hills, CA: SAGE Publications.

\section{ADDITIONAL READING}

Eckhardt, J., Aapaoja, A., Nykänen, L., Sochor, J., Karlsson, M., \& König, D. (2018). The European Roadmap 2025 for Mobility as a Service. In Proceedings of 7th Transport Research Arena TRA 2018. Vienna.

International Association of Public Transport. (2019). Mobility as a Service. Brussels: International Association of Public Transport (UITP). Retrieved from https://www. uitp.org/sites/default/files/cck-focus-papers-files/Report_MaaS_final.pdf

Jeekel, H. (2017). Social Sustainability and Smart Mobility: Exploring the relationship. Transportation Research Procedia, 25,4296-4310. doi:10.1016/j.trpro.2017.05.254

Kamargianni, M., Li, W., Matyas, M., \& Schäfer, A. (2016). A critical review of new mobility services for urban transport. Transportation Research Procedia, 14, 3294-3303. doi:10.1016/j.trpro.2016.05.277

Mulley, C. (2017). Mobility as a Services (MaaS) - does it have critical mass? Transport Reviews, 37(3), 247-251. doi:10.1080/01441647.2017.1280932

National Academies of Sciences, Engineering, and Medicine. (2016). Between Public and Private Mobility: Examining the Rise of Technology-Enabled Transportation Services. Washington, DC: The National Academies Press. doi:10.17226/21875

Sochor, J., Strömberg, H., \& Karlsson, I. C. M. (2015). Implementing Mobility as a Service: Challenges in Integrating User, Commercial, and Societal Perspectives. Transportation Research Record: Journal of the Transportation Research Board, 4(2536), 1-9. doi:10.3141/2536-01

Strömberg, H., Karlsson, I. C. M., \& Sochor, J. (2018). Inviting travelers to the smorgasbord of sustainable urban transport: Evidence from a MaaS field trial. Transportation, 45(6), 1655-1670. doi:10.100711116-018-9946-8 


\section{KEY TERMS AND DEFINITIONS}

Collaborative Economy: Sharing, lending/borrowing, or renting products (e.g., vehicles) without the need to own them. Also participating in services together. A way to increase resource efficiency assisted by digital platforms.

Demand-Responsive Transport: A transport service that operates according to client needs in a specific zone and time slots without predefined routes or schedules.

Mobility as a Service: A concept that integrates different transport services, such as public transport, sharing services and taxi. Services are offered on a one-stopshop principle utilizing digitalization and including e.g. multimodal route planning and mobile ticketing and payment. Additional services may also be included, such as freight.

Peer-to-Peer: Private people offering services to other private people.

Prosumer: A consumer who also produces services. Regarding transport services, prosuming may refer, for example, to peer-to-peer carsharing, ridesharing of people and goods, and organized hitchhiking.

Public-Private-People Partnership: A form of collaboration between public and private sectors as well as users ('people'). In the context of transport services, 'people' can be considered as prosumers.

Ridesharing: Private people offering rides or goods deliveries to other private people.

Ridesourcing: A transport service based on smartphone application that connects passengers and drivers. Instead of commercial vehicles, drivers typically use their own car.

Statutory Transportation: A transportation service that according to legislation has to be offered to all citizens fulfilling certain criteria. This may refer to reduced mobility capabilities of handicapped and elderly people.

Subsidized Transportation: A transportation service that is not fully market based and receives financial support from the public sector. 